\title{
Comparison of two commercial broad- range PCR and sequencing assays for identification of bacteria in culture-negative clinical samples
}

\author{
Camilla Stavnsbjerg ${ }^{1,2}$, Niels Frimodt-Møller ${ }^{1}$, Claus Moser ${ }^{1}$ and Thomas Bjarnsholt ${ }^{1,2^{*}}$ (D)
}

\begin{abstract}
Background: Culturing has long been the gold standard for detecting aetiologic agents in bacterial infections. In some cases, however, culturing fails to detect the infection. To further investigate culture-negative samples, amplification and subsequent sequencing of the 16S rRNA gene is often applied. The aim of the present study was to compare the current method used at our Department of Clinical Microbiology, based on the MicroSeq ID system (Applied Biosystems, USA) with the Universal Microbe Detection (UMD) SelectNA kit (Molzym, Germany).

Methods: 76 culture-negative samples were first processed with the MicroSeq ID analysis, where total DNA was extracted and the 165 gene amplified and sequenced with the MicroSeq ID system. Samples were subsequently processed with the UMD SelectNA analysis, where human DNA was removed during the DNA extraction procedure and the 165 gene amplified in a real-time PCR and sequenced.

Results: 22 of 76 samples (28.9\%) were positive for bacteria with the UMD SelectNA, which was significantly more ( $p=0.0055)$ than the MicroSeq ID where 11 of 76 samples (14.5\%) were positive. The UMD SelectNA assay identified more relevant bacterial pathogens than the MicroSeq ID analysis $(p=0.0233)$, but also found a number of species that were considered contaminations.

Conclusions: The UMD SelectNA assay was valuable for the identification of pathogens in culture-negative samples; however, due to the sensitive nature of the assay, extreme care is suggested in order to avoid false positives.
\end{abstract}

Keywords: Culture-negative samples, Molecular diagnostics, Universal Microbe Detection, 16S PCR

\section{Background}

The standard method used in clinical microbiology laboratories for detection of bacterial and fungal pathogens is culturing of clinical specimens obtained from the patients. However, in some infectious episodes, the causative microorganism cannot be detected by culturing, even though the clinical signs and symptoms are suggestive of an infection. The occurrence of culturenegative results, when microorganisms are in fact

\footnotetext{
* Correspondence: tbjarnsholt@sund.ku.dk

'Department of Clinical Microbiology, Centre for Diagnostics, Rigshospitalet, Copenhagen, Denmark

2Department of Immunology and Microbiology, Faculty of Health and Medical Sciences, University of Copenhagen, Copenhagen, Denmark
}

present, can be due to prior antibiotic treatment [1], slow growing or fastidious microorganisms [2], or the presence of viable but nonculturable bacteria [3]. Culture-negative results are for instance seen with infective endocarditis [4], bone and joint infections including foreign body associated infections [5], otitis media [6], and meningitis [7].

Molecular methods have the potential to detect and identify pathogens that are nonculturable. One such method is PCR that identifies pathogens from their nucleic acids. Several types of PCRs can be used depending on purpose, such as species-specific PCRs, multiplex PCRs that targets a panel of species, or broad-range PCRs that potentially targets all species. At the 
Department of Clinical Microbiology at Rigshospitalet, part of a tertiary-referral hospital, samples are received from diverse infections with different etiologies. A broad-range PCR assay was implemented seven years ago in the department in order to identify pathogens in culture-negative samples from patients with a suspected infection. The method in use consists of a total genomic DNA extraction from the clinical samples followed by broad-range $16 \mathrm{~S}$ rDNA PCR and sequencing analyses employing the MicroSeq ID kit. This led to an improved detection rate of infectious episodes when compared with culturing. However, a substantial number of samples still tested negative for microorganisms despite continued clinical suspicion of infection, indicating a suboptimal sensitivity.

The commercial broad-range UMD assay (also known as SepsiTest when performed on whole blood) has previously been shown to have an increased positivity rate compared to culturing for a variety of samples [8-11]. The assay includes a DNA extraction, in which human DNA is removed, followed by a PCR amplifying regions of the $16 \mathrm{~S}$ and $18 \mathrm{~S}$ genes. The assay has been reported by the company to have a lower detection limit of 20-460 colony forming units (CFU) per $\mathrm{mL}$ blood depending on species [12]. A semi-automated version of the assay, i.e. the UMD SelectNA, requiring less hands-on time has been developed since the previous studies. The aim of this study was to compare the MicroSeq ID analysis with the UMD SelectNA assay for the detection and identification of pathogens in culture-negative samples for routine diagnostic purposes.

\section{Methods}

\section{Sample collection}

Samples from patients with a suspected infection were collected under sterile conditions at either Rigshospitalet (a tertiary referral hospital, 1361 bed units, approximately 264,000 inpatients annually) or Hvidovre Hospital (a secondary referral hospital, 730 bed units, approximately 83,000 inpatients annually), and sent to the Department of Clinical Microbiology (DCM) at Rigshospitalet during the period of June 2015 to October 2015. Sample types included tissue adjacent to joints (27), other tissues (12), bone samples (9), body fluids (6), heart valves (5), joint fluids (5), foreign bodies (3), spinal fluids (3), pus (3), sonication fluids (2), E-swap (1). Culture-negative samples, from patients with a suspected infection, were subjected to MicroSeq ID $16 \mathrm{~S}$ if requested by the clinical doctor responsible for the treatment of the patient. The same samples were subsequently processed with the UMD SelectNA assay. Specimens were stored at $5{ }^{\circ} \mathrm{C}$ upon arrival at the DCM, and processed within four weeks.

\section{Culturing}

All growth media were obtained from Statens Serum Institute, Denmark. All samples were cultured for up to 5 days with the exception of heart valves that were cultured up to 14 days. For culture conditions see Table 1. The MALDI-TOF Biotyper (Bruker, Germany) was used to identify isolates.

\section{UMD SelectNA assay DNA isolation}

DNA isolation was performed with the UMD SelectNA CE-IVD kit (Molzym, Germany) according to the manufacturer's recommendation. In short, tissue samples were pre-treated with proteinase $\mathrm{K}$ for $10 \mathrm{~min}$. Body fluids, swabs and tissues were treated with a chaotropic buffer, lysing the human cells, and subjected to DNase treatment to degrade the human DNA. DNA from potentially present microorganisms was subsequently extracted in the SelectNA instrument and stored at $-20{ }^{\circ} \mathrm{C}$ until realtime PCR analysis.

\section{Real-time PCR}

The real-time PCR assay was carried out with reagents from the UMD SelectNA kit. Two PCRs were performed for each sample: 1) a reaction amplifying the V3-V4 region of the bacterial $16 \mathrm{~S}$ rDNA gene (481 bp); and 2) a control reaction amplifying a DNA fragment that was added during the DNA extraction to evaluate the efficiency of the extraction. The SYBR green based realtime PCR was perfomed in a LightCycler 480 instrument (Roche, Switzerland) with the following conditions: $95{ }^{\circ} \mathrm{C}$ for $1 \mathrm{~min} ; 40$ cycles of $95{ }^{\circ} \mathrm{C}$ for $5 \mathrm{~s}, 55{ }^{\circ} \mathrm{C}$ for $10 \mathrm{~s}$ and $72{ }^{\circ} \mathrm{C}$ for $25 \mathrm{~s}$ followed by a melting curve analysis (70-95 $\left.{ }^{\circ} \mathrm{C}\right)$. Samples with a melting temperature $\left(\mathrm{T}_{\mathrm{m}}\right)$ value between 87 and $91{ }^{\circ} \mathrm{C}$ for the 16S were considered positive.

\section{Sequencing}

PCR products from positive samples were purified with the QIAquick PCR purification kit (Qiagen, Netherlands). Sequencing primers included in the UMD SelectNA kit were used for Sanger sequencing, performed by Macrogen (Amsterdam, Netherland). Sequences were initially aligned to the SepsiTest BLAST database (http://www.sepsitest-blast.de) and subsequently if no bacterial species was identified by the database, to the NCBI BLAST database (http://www.ncbi.nlm. nih.gov/BLAST/). Sequences with $\geq 97-99 \%$ or $\geq 99 \%$ identity to the database were assigned to genus level or species level, respectively. Mixed bacterial sequences were analyzed with the RipSeq mixed program (Pathogenomix, USA) to resolve the individual sequences [13]. 
Table 1 Culturing conditions

\begin{tabular}{|c|c|c|c|c|c|c|c|}
\hline & $\begin{array}{l}\text { Anaerobic plates } \\
\text { (anaerobic conditions) }\end{array}$ & $\begin{array}{l}\text { Chocolate agar plates } \\
\text { (aerobic, } 5 \% \mathrm{CO}_{2} \text { ) }\end{array}$ & $\begin{array}{l}\text { Blood agar plates } \\
\text { (aerobic, } 5 \% \mathrm{CO}_{2} \text { ) }\end{array}$ & $\begin{array}{l}\text { Eosin methylene } \\
\text { blue plates (aerobic) }\end{array}$ & $\begin{array}{l}\text { Brain heart infusion } \\
\text { agar plates (anaerobic) }\end{array}$ & $\begin{array}{l}\text { Thioglycolate } \\
\text { broth (aerobic) }\end{array}$ & $\begin{array}{l}\text { Serum bouillon } \\
\text { broth (aerobic) }\end{array}$ \\
\hline $\begin{array}{l}\text { Soft tissue and } \\
\text { body fluids }\end{array}$ & $x$ & $x$ & $x$ & $x$ & & $x$ & $x$ \\
\hline Bone samples & $x$ & $x$ & $x$ & $x$ & & $x$ & \\
\hline Heart valves & $x$ & $x$ & $x$ & $x$ & & & \\
\hline Pus samples & & $x$ & X & $x$ & $x$ & $x$ & \\
\hline
\end{tabular}

\section{Precautions to avoid contamination}

DNA isolation and addition of DNA to the PCR was carried out in a laminar flow bench in a room designated for extraction procedures. The master mix was prepared in a laminar flow bench in a DNA-free master-mix room. All surfaces of benches and equipment were cleaned with the disinfectant Virkon (Virkon Disinfectant Technologies, UK) before use. A $1 \mathrm{~h}$ UV decontamination program was performed on the SelectNA instrument before every use. Sterile elbow-long gloves and designated lab coats were used at all times.

\section{MicroSeq ID $16 \mathrm{~S}$ analysis DNA isolation}

Samples were processed with the DNeasy Blood and Tissue kit (Qiagen, Netherlands) according to the manufacturer's tissue protocol with a few modifications: after $56{ }^{\circ} \mathrm{C}$ incubation with proteinase $\mathrm{K}$ for $2-3 \mathrm{~h}$, samples were incubated for additional $10 \mathrm{~min}$ at $95{ }^{\circ} \mathrm{C}$, and the final elution volume was $100 \mu \mathrm{L}$ AE buffer. DNA solutions from all tissue samples were diluted 1:40 in nuclease-free water.

\section{PCR}

The MicroSeq 500 16S rDNA PCR (Applied Biosystems, United States) was used to amplify the V1-V2 region of the 16S. Sample DNA and the master mix were mixed in a 1:1 ratio and the reaction was carried out in a 9800 Fast Thermal Cycler (Applied Biosystems, USA) with the following conditions: initial denaturation of $95{ }^{\circ} \mathrm{C}$ for $10 \mathrm{~min}$ and 30 cycles of $95{ }^{\circ} \mathrm{C}$ for $30 \mathrm{~s}, 60{ }^{\circ} \mathrm{C}$ for $30 \mathrm{~min}$ and $72{ }^{\circ} \mathrm{C}$ for $45 \mathrm{~s}$, followed by a final extension of $72{ }^{\circ} \mathrm{C}$ for $10 \mathrm{~min}$. PCR products were resolved by electrophoresis on a $2 \%$ agarose gel (Embi Tech, United States). Samples with a 500$600 \mathrm{bp}$ PCR fragment were purified with the ExoSap-IT kit (Affymetrix, United States).

\section{Sequencing}

PCR products were sequenced with the MicroSeq $50016 \mathrm{~S}$ Seq kit (Applied Biosystems, United States) according to manufacturer's instructions. Products were then purified with gel filtration cartridges (Edge Bio, Unites States) and sequenced on a 3130xl Genetic Analyzer (Applied
Biosystems, Unites States). The MicroSeq ID software was used to identify the species and in cases with low match \% the sequence was additionally aligned to the NCBI BLAST database.

\section{Precautions to prevent contamination}

DNA extraction and PCR setup was performed in a preamplification room separated from the post-amplification room where the sequencing was performed. Gloves and designated lab coats were applied.

\section{Evaluation of results and statistics}

A comparison was performed on the sequencing results obtained by the two methods and other findings from the same patient, including: culturing, molecular analyses, histopathology and serology. A finding was considered a relevant pathogen when the same organism was identified in another sample from the same patient by culturing or molecular analysis, or when histopathology or serology supported the finding. Findings with no such support were considered ambiguous. McNemar's test was performed on $2 \times 2$ contingency Tables. A $p$-value below 0.05 was considered significant.

\section{Results}

\section{Positivity rate of the two methods}

76 culture-negative samples originating from 46 patients were processed with both the MicroSeq ID analysis and the UMD SelectNA assay. A total of 22 samples (28.9\%) were positive with the UMD SelectNA assay, which was significant more compared to the 11 positive samples $(14.5 \%)$ with the MicroSeq ID $(p=0.0055)$ (Table 2$)$.

Table 2 Summary of all results

\begin{tabular}{lllll}
\hline All samples & MicroSeq ID & & & \\
\hline UMD SelectNA & & + & - & Total \\
& + & 10 & 12 & 22 \\
& - & 1 & 53 & 54 \\
& Total & 11 & 65 & 76 \\
\hline
\end{tabular}

$+=$ positive, $-=$ negative. A McNemar's test was performed, $p=0.0055$ 


\section{Concordance}

Ten samples were positive with both the MicroSeq ID analysis and the UMD SelectNA analysis (Table 3). The same organisms were found with the two methods with the exception of one pus sample from a cerebral abscess, which showed only partial concordance. The MicroSeq ID identified Fusobacterium nucleatum and Parvimonas micra while the UMD SelectNA identified Dialister pneumocitis and Parvimonas micra (ID 3). All identified species are common pathogens found in abscesses with an odontogenic origin and therefore considered clinically relevant [14].

\section{Discordance}

Twelve samples were positive with the UMD SelectNA analysis and negative with the MicroSeq ID analysis, whereas only one sample was positive with the MicroSeq ID analysis and negative with the UMD SelectNA analysis (Table 4). The results were compared to other findings from the patients obtained within the last year in order to evaluate the relevance of the findings, and based on this categorized as either relevant findings (R) or ambiguous findings (A).

The UMD SelectNA identified relevant pathogens in 7 samples (ID 6, 9-12) of which the MicroSeq ID analysis were negative. One relevant pathogen, i.e. Toxoplasma gondii, was only detected by the MicroSeq ID (ID 13, cerebral abscess). The number of positive samples with relevant bacterial species were significantly higher using the UMD SelectNA compared to the MicroSeq ID $(p=0.0233)$ (Table 5$)$. In the remaining 5 samples bacterial species were considered ambiguous findings because the results were not confirmed by other findings. The Bacillus species and Thiothrix flexilis detected in tissue located adjacent to an infected prosthesis (ID 14) were most likely contaminants as where the Staphylococcus epidermidis found in a lymph node from a lymphoma patient (ID 18). Kocuria rhizophila (ID 15, pericarditis) and Bergeyella sp. $H 1890$ (ID 17, spondylodiscitis) have been reported to cause human disease $[15,16]$ while Cloacibacterium normanense (ID 17, spondylodiscitis) and Hymenobacter arizonensis (ID 16, spondylodiscitis) are not typically associated with human infections, but have been detected at surgical wound sites [17].

\section{Discussion}

Seventy-six culture-negative samples from patients with suspected infection were analyzed with the MicroSeq ID analysis and the UMD SelectNA analysis. The UMD SelectNA method identified significantly more relevant bacterial pathogens than the MicroSeq ID analysis, and thus proved to be a more sensitive analysis for detecting bacteria. It is possible that the removal of human DNA during the UMD SelectNA method explains the higher sensitivity, since excessive amounts of human DNA has been shown to inhibit the $16 \mathrm{~S}$ PCR reaction [18]. The singule case (ID 13) where the MicroSeq ID analyses detected a pathogen not detected by the UMD SelectNA analysis was in a pus sample from a cerebral abscess. In this case the intracellular parasite Toxoplasma gondii was identified as demonstrated earlier with this method [19]. It is possible that the chaotropic buffer intended to lyse the human cells during the UMD SelectNA DNA extraction disrupted the membrane of the parasite and exposed the DNA to the DNase activity.

In another case of cerebral abscess (ID 3) the two methods identified different oral-cavity-derived bacterial species that were all considered relevant. Often multiple

Table 3 Concordant result of the UMD SelectNA and MicroSeq ID methods

\begin{tabular}{|c|c|c|c|c|c|}
\hline Patient ID & Sample type & Indication & UMD SelectNA result & MicroSeq ID result & Other findings ${ }^{a}$ \\
\hline 1 & Aorta tissue & Endocarditis & Streptococcus pyogenes & S. pyogenes & $\begin{array}{l}\text { S. pyogenes cultured from } \\
\text { blood sample }\end{array}$ \\
\hline 2 & Heart valve tissue & Endocarditis & Staphylococcus aureus/simiae & S. aureus & $\begin{array}{l}\text { S. aureus cultured from } \\
\text { blood sample }\end{array}$ \\
\hline 3 & Pus & Cerebral abscess & $\begin{array}{l}\text { Dialister pneumocitis \& } \\
\text { Parvimonas micra }\end{array}$ & $\begin{array}{l}\text { Fusobacterium nucleatum \& } \\
\text { P. micra }\end{array}$ & $\begin{array}{l}\text { F. nucleatum cultured from } \\
\text { blood sample }\end{array}$ \\
\hline 4 & Seroma fluid & Breast cancer & Streptococcus mitis/oralis & S. mitis & \\
\hline 5 & Pus & Abscess in fossa iliaca & Streptococcus intermedius & S. intermedius & \\
\hline \multirow[t]{3}{*}{6} & Tissue & Infected hip prosthesis & $\begin{array}{l}\text { Streptococcus dysgalactiae } \\
\text { equisimilis }\end{array}$ & S. dysgalacticae equisimilis & \\
\hline & Tissue & & S. dysgalactiae equisimilis & S. dysgalacticae equisimilis & \\
\hline & Tissue & & S. dysgalactiae equisimilis & S. dysgalacticae equisimilis & \\
\hline 7 & Aorta valve & Endocarditis & S. pyogenes & S. pyogenes & \\
\hline 8 & Aorta valve & Endocarditis & Streptococcus anginosus & S. anginosus & $\begin{array}{l}\text { S. anginosus cultured from } \\
\text { blood samples }\end{array}$ \\
\hline
\end{tabular}

${ }^{\mathrm{a}}$ Findings from other sample taken from the same patient 
Table 4 Discordant result of the UMD SelectNA and MicroSeq ID methods

\begin{tabular}{|c|c|c|c|c|c|c|}
\hline Patient ID & Sample type & Indication & UMD SelectNA result & MicroSeq ID result & Other findings & Conclusion \\
\hline 6 & Tissue & Infected hip prosthesis & S. dysgalactiae equisimilis & - & $\begin{array}{l}\text { S. dysgalactiae equisimilis found } \\
\text { with } 165 \text { in } 3 \text { other samples } \\
\text { from the patient }\end{array}$ & $\mathrm{R}$ \\
\hline 9 & Tissue & Mycotic aneurism & S. pneumoniae & - & $\begin{array}{l}\text { Cocci found in blood culture } \\
\text { bottle and positive antibody } \\
\text { reaction for pneumococci }\end{array}$ & R \\
\hline 10 & Tissue & Spinal implant infection & $\begin{array}{l}\text { Staphylococcus lundunensis/ } \\
\text { hominis }\end{array}$ & - & $\begin{array}{l}\text { Staphylococcus hominis cultured } \\
\text { from tissue sample }\end{array}$ & $\mathrm{R}$ \\
\hline \multirow[t]{2}{*}{11} & Tissue & \multirow[t]{2}{*}{ Infected knee prosthesis } & S. aureus/simiae & - & \multirow[t]{2}{*}{ S. aureus cultured from tissue } & R \\
\hline & Tissue & & S. aureus/simiae & - & & R \\
\hline \multirow[t]{2}{*}{12} & Tissue & \multirow[t]{2}{*}{ Infected hip prosthesis } & $\begin{array}{l}\text { Staphylococcus epidermidis/ } \\
\text { caprae/capitis }\end{array}$ & - & \multirow[t]{2}{*}{$\begin{array}{l}\text { S. epidermidis cultured in } 3 \text { out } \\
\text { of } 5 \text { biopsies }\end{array}$} & R \\
\hline & Tissue & & S. epidermidis/caprae/capitis & - & & \\
\hline 13 & Tissue & Cerebral abscess & - & $\begin{array}{l}\text { Toxoplasma gondii } \\
\text { (parasite) }\end{array}$ & & R \\
\hline 14 & Tissue & Infected hip prosthesis & Bacillus sp. \& Thiotrix sp. & - & $\begin{array}{l}\text { Two other tissue samples } \\
\text { negative with the UMD and } \\
\text { routine } 16 \mathrm{~S} / 28 \mathrm{~S}\end{array}$ & A \\
\hline 15 & $\begin{array}{l}\text { Fluid from pacemaker } \\
\text { electrode }\end{array}$ & Pericarditis & Kocuria rhizophila & - & $\begin{array}{l}\text { Two other samples negative } \\
\text { with UMD and routine } 16 \mathrm{~S} / 28 \mathrm{~S}\end{array}$ & A \\
\hline 16 & Implantation material & Spondylodiscitis & Hymenobacter arizonensis & - & $\begin{array}{l}\text { Other implant material sample } \\
\text { negative with UMD and routine } \\
16 \mathrm{~S} / 28 \mathrm{~S}\end{array}$ & A \\
\hline 17 & Tissue & Spondylodiscitis & $\begin{array}{l}\text { Cloacibacterium normanense \& } \\
\text { Bergeyella sp. H1890 }\end{array}$ & - & $\begin{array}{l}\text { Fluid from back negative with } \\
\text { UMD and routine } 16 S / 28 S\end{array}$ & A \\
\hline 18 & Lymph node & Lymphoma & S. epidermidis & - & & A \\
\hline
\end{tabular}

species are associated with cerebral abscesses of odontogenic origin [14], and it is well known that Sanger sequencing of the $16 \mathrm{~S}$ gene is limited to detecting two or perhaps three species [20]. In order to obtain a higher resolution, next generation sequencing must be applied.

In addition to the relevant pathogens, the UMD SelectNA method also identified a number of ambiguous findings. The broad-range nature of the assay combined with the low detection limit make the assay sensitive to contamination, since only a few bacteria introduced during sampling, handling or processing of the sample will give rise to a positive result. A limitation in this study was that the UMD SelectNA assay was performed on leftover material. Patient samples were primarily used for culture-based identification, subsequently for the $16 \mathrm{~S}$ MicroSeq ID analyses and finally for the UMD SelectNA

Table 5 Results of samples with relevant bacterial species only

\begin{tabular}{lllll}
\hline Samples with relevant bacteria & \multicolumn{4}{l}{ MicroSeq ID } \\
\hline UMD SelectNA & & + & - & Total \\
& + & 10 & 7 & 17 \\
& - & 0 & 59 & 59 \\
& Total & 10 & 66 & 76
\end{tabular}

$+=$ positive for a relevant bacterial species, $-=$ negative for a relevant bacterial species. A McNemar's test was performed, McNemar's test $p=0.0233$ assay. Therefore, it is possible that samples were contaminated in the process of handling. However, similar studies evaluating the manual version of the UMD assay found a corresponding number of unlikely bacteria in different clinical specimens that they considered environmental contaminants [21, 22]. Haag et al. [21] states that material already processed for other purposes than molecular diagnosis is of limited value and that samples should be spilt upon arrival to the laboratory . However, at our Department of Clinical Microbiology, molecular analysis is often ordered after culturing has proven negative, and due to the large number of samples received every day it is not feasible to divide all the samples in case they are send for molecular analysis later. Thus, in this study we have demonstrated that samples used for culturing can still be of value for detecting relevant pathogens with molecular methods. Also, it cannot be excluded that the rare bacterial species identified with the UMD SelectNA assay are causative of the infection. Indeed, these events should be monitored to elucidate their true nature.

Samples were stored at $5{ }^{\circ} \mathrm{C}$ to avoid potential cell disruption from freezing and thawing that would result in digestion of exposed microbial DNA and the occurrence of false negatives with the UMD SelectNA. To evaluate the possible contamination risk of storing the samples at 
this temperature, seven bone samples from healthy donors where processed with the UMD SelectNA both upon arrival at the Department of Clinical Microbiology and 4 weeks later. All $16 \mathrm{~S}$ real-time PCR reactions were negative, indicating that no contamination had occurred (data not shown).

Even with the increased sensitivity of the SelectNA analysis the majority of the samples were negative (70.7\%). This could be due to 1 ) the patient did not have an infection, 2) the amount of bacteria in the sample was below the detection limit of the method or 3) the sample did not contain any bacteria even though the patient had an infection. Many of the samples in this study were collected from patients with chronic infections where it has been shown that the bacteria are not homogeneously distributed at the infectious site [23, 24], and that they can be caused by bacteria growing in small biofilms down to $5 \mu \mathrm{m}$ [25]. In these cases, sampling of the infected area is extremely difficult. At least two patients with negative results did have an infection. Three bone samples from one patient, suspected of having a tuberculosis osteomyelitis, were positive with a Mycobacteriumtuberculosis-specific PCR performed at another diagnostic laboratory (State Serum Institute, SSI). Additionally, another patient suspected of having an atypical mycobacterial infection tested positive for Mycobacterium avium at the SSI. Mycobacteria species are included in the list of bacteria that can be detected by the assay, but the thick cell wall of mycobacteria species has previously proved to be difficult to disrupt $[26,27]$. It is possible that the chemical and enzymatic lysis in the UMD SelectNA assay is not sufficient for disrupting the mycobacterial cells.

This study is, to the authors' knowledge, the first to report on the performance of the semi-automated version of UMD assay, i.e. the SelectNA, which has a definite shorter hands-on time than the manual version. Comparison of this study to previously published studies of the manual version is somewhat difficult due to the difference of study design and sample types. All previous studies have compared the UMD assay (or SepsiTest) with culturing, in contrast to this study where all samples included were culture negative, consequently they were able to calculate sensitivity and specificity of the method by comparing to culturing results. Whether it is relevant to use culturing as the gold standard when culturing does not find all pathogens is debatable. Here it was chosen not to calculate sensitivity and specificity for the methods in lack of a reliable gold standard. Kühn et al. applied the method for diagnosis of infectious endocarditis and reported a sensitivity of $85 \%$ with the UMD [11]; this study likewise found a high positivity rate for heart valves with three out of five positive for relevant pathogens. Haag et al. found 37.9\% culturenegative but PCR positive with the UMD assay, which is more than the $28.9 \%$ found in this study [21]. A possible explanation of this discrepancy might be that Rigshospitalet is a large tertiary referral hospital with patients suffering from rare diseases where the etiology is difficult to elucidate. In any case both studies demonstrate that the UMD is applicable to many different samples types, which is convenient in a diagnostic laboratory receiving many different sample types. Recently, a new version of the SelectNA instrument fully automating the DNA extraction for fluid samples and only requiring a short manual pre-treatment for tissue has been developed. The DNA extraction involves less hands-on time and is currently being tested at the Department.

\section{Conclusion}

In summary, the UMD SelectNA assay was found to be more sensitive than the MicroSeq ID analysis currently used at the Department of Clinical Microbiology, and therefore valuable for detecting pathogens in culturenegative samples. Because of the increased sensitivity, the assay is sensitive to contamination. Therefore, aseptic handling of the samples and a thorough clinical evaluation of the patient's history is vital in order to assess the relevance of the findings.

\section{Abbreviation \\ PCR: Polymerase chain reaction; UMD: Universal Microbe Detection}

\section{Acknowledgments}

We would like to thank Pia Poss, Maria K. Björnsdóttir, Maria Louise B. Kristensen, Maryam Kavani and Sirin Soyler for processing the samples with the MicroSeq ID method as part of the daily routine diagnostics in the Department of Clinical Microbiology at Rigshospitalet.

\section{Funding}

This study was supported by grants from the Lundbeck Foundation that had no role in designing, performing or reporting of this study.

\section{Availability of data and material \\ The datasets used and/or analysed during the current study are available from the corresponding author on reasonable request.}

\section{Authors' contributions}

CS performed data collection, data analysis and wrote the majority of the manuscript. CM provided the medical judgement of the relevance of the findings in relation to the patient history and commented on the

manuscript. NFM gave permission for the study to commence, provided financial support from hospital funds and commented on the manuscript. TB designed the study and participated in writing of the manuscript. All authors read and approved the final manuscript.

\section{Competing interests}

The authors declare that they have no competing interests.

\section{Consent for publication}

Not applicable.

\section{Ethics approval and consent to participate}

According to Danish legislation, a comparison of two molecular assays for quality assurance is not a health research project, as defined by the 'Danish Act on Research Ethics Review of Health Research Projects'. Therefore, no approval from the Committees on Health Research Ethics in the Capital Region of Denmark was needed. 


\section{Publisher's Note}

Springer Nature remains neutral with regard to jurisdictional claims in published maps and institutional affiliations.

Received: 21 December 2016 Accepted: 21 March 2017

Published online: 27 March 2017

\section{References}

1. Rampini SK, Bloemberg G V, Keller PM, Büchler AC, Dollenmaier G, Speck RF et al. Broad-range $16 \mathrm{~S}$ rRNA gene polymerase chain reaction for diagnosis of culture-negative bacterial infections. Clin Infect Dis. 2011 [cited 2014 Dec 19];53:1245-51. Available from: http://www.ncbi.nlm.nih.gov/pubmed/ 21976460.

2. Zimmerli W, Trampuz A, Ochsner PE. Prosthetic-joint infections. N Engl J Med. 2004:351:1645-54. Available from: http://www.ncbi.nlm.nih.gov/ pubmed/15483283

3. Li L, Mendis N, Trigui H, Oliver JD, Faucher SP. The importance of the viable but non-culturable state in human bacterial pathogens. Front Microbiol. 2014;5:1-1.

4. Marín M, Muñoz $P$, Sánchez $M$, del Rosal $M$, Alcalá $L$, Rodríguez-Créixems $M$, et al. Molecular diagnosis of infective endocarditis by real-time broad-range polymerase chain reaction (PCR) and sequencing directly from heart valve tissue. Medicine (Baltimore). 2007 [cited 2014 Feb 17];86:195-202. Available from: http://www.ncbi.n/m.nih.gov/pubmed/17632260.

5. Costerton JW. Biofilm theory can guide the treatment of device-related orthopaedic infections. Clin Orthop Relat Res. 2005 [cited 2014 Dec 30];7-11. Available from: http://www.ncbi.nlm.nih.gov/pubmed/16056019.

6. Rayner MG, Zhang Y, Gorry MC, Chen Y, Post JC, Ehrlich GD. Evidence of bacterial metabolic activity in culture-negative otitis media with effusion. JAMA. 1998;279:296-9.

7. Welinder-Olsson C, Dotevall L, Hogevik H, Jungnelius R, Trollfors B, Wahl M, et al. Comparison of broad-range bacterial PCR and culture of cerebrospinal fluid for diagnosis of community-acquired bacterial meningitis. Clin Microbiol Infect. European Society of Clinical Infectious Diseases; 2007 [cited 2014 Dec 29];13:879-86. Available from: http://www.ncbi.nlm.nih. gov/pubmed/17608746.

8. Wellinghausen N, Kochem A-J, Disqué C, Mühl H, Gebert S, Winter J, et al. Diagnosis of bacteremia in whole-blood samples by use of a commercial universal 165 rRNA gene-based PCR and sequence analysis. J Clin Microbiol. 2009 [cited 2013 Nov 9];47:2759-65. Available from: http:// www.pubmedcentral.nih.gov/articlerender.fcgi?artid=2738079\&tool= pmcentrez\&rendertype $=$ abstract

9. Meyer T, Franke G, Polywka SK a, Lütgehetmann M, Gbadamosi J, Magnus T, et al. Improved detection of bacterial central nervous system infections by use of a broad-range PCR assay. J Clin Microbiol. 2014 [cited 2014 May 1]; 52:1751-3. Available from: http://www.ncbi.nlm.nih.gov/pubmed/24622094.

10. Grif K, Heller I, Prodinger WM, Lechleitner K, Lass-Flörl C, Orth D. Improvement of detection of bacterial pathogens in normally sterile body sites with a focus on orthopedic samples by use of a commercial 165 rRNA broad-range PCR and sequence analysis. J Clin Microbiol. 2012 [cited 2014 Apr 30];50:2250-4. Available from: http://www.pubmedcentral.nih.gov/articlerender.fcgi?artid= 3405601\&tool=pmcentrez\&rendertype=abstract.

11. Kühn $C$, Disqué $C$, Mühl $H$, Orszag $P$, Stiesch $M$, Haverich A. Evaluation of commercial universal rRNA gene PCR plus sequencing tests for identification of bacteria and fungi associated with infectious endocarditis. J Clin Microbiol. 2011 [cited 2014 Mar 7];49:2919-23. Available from: http://www.pubmedcentral.nih.gov/articlerender. fcgi?artid=3147771\&tool=pmcentrez\&rendertype=abstract.

12. Mühl H, Kochem A-J, Disqué C, Sakka SG. Activity and DNA contamination of commercial polymerase chain reaction reagents for the universal $16 \mathrm{~S}$ rDNA real-time polymerase chain reaction detection of bacterial pathogens in blood. Diagn Microbiol Infect Dis. 2010;66(1):41-9.

13. Wolff TY, Eickhardt S, Björnsdottir MK, Moser C, Bjarnsholt T, Høiby N, et al. Direct sequencing and RipSeq interpretation as a tool for identification of polymicrobial infections. J Clin Microbiol. 2013 [cited 2015 Jan 4];51:1281-4. Available from: http://www.pubmedcentral.nih.gov/articlerender.fcgi?artid= 3666778\&tool=pmcentrez\&rendertype=abstract.

14. Brook I. Microbiology of intracranial abscesses associated with sinusitis of odontogenic origin. Ann Otol Rhinol Laryngol. 2006;115:917-20.

15. Moissenet D, Becker K, Mérens A, Ferroni A, Dubern B, Vu-Thien H. Persistent bloodstream infection with Kocuria rhizophila related to a damaged central catheter. J Clin Microbiol. 2012;50:1495-8. Available from: http://www pubmedcentral.nih.gov/articlerender.fcgi?artid=3318534\&tool= pmcentrez\&rendertype $=$ abstract

16. Shukla SK, Paustian DL, Stockwell PJ, Morey RE, Jordan JG, Levett PN, et al, Isolation of a fastidious Bergeyella species associated with cellulitis after a cat bite and a phylogenetic comparison with Bergeyella zoohelcum strains. J Clin Microbiol. 2004;42:290-3. Available from: http://www.pubmedcentral.nih. gov/articlerender.fcgi?artid $=321680 \&$ tool $=$ pmcentrez\&rendertype $=$ abstract

17. Romano-Bertrand S, Frapier J-M, Calvet B, Colson P, Albat B, Parer S, et al. Dynamics of the surgical microbiota along the cardiothoracic surgery pathway. Front Microbiol. 2014:5:787. Available from: http://www. pubmedcentral.nih.gov/articlerender.fcgi?artid=4292786\&tool= pmcentrez\&rendertype $=$ abstract

18. Bémer P, Plouzeau C, Tande D, Léger J, Giraudeau B, Valentin AS, et al. Evaluation of 165 rDNA PCR Sensitivity and Specificity for Diagnosis of Prosthetic-Joint Infection: a prospective multicenter cross-sectional study. J Clin Microbiol. 2014;52:3583-9. Available from: http://jcm.asm.org/content/ 52/10/3583.abstract?etoc

19. Kruse AYC, Kvich L, Eickhardt S, Omland LH, Bjarnsholt T, Moser C. Unexpected diagnosis of cerebral toxoplasmosis by 165 and D2 large-subunit ribosomal DNA PCR and sequencing. J Clin Microbiol. 2015;53:1983-5.

20. Kommedal $\varnothing$, Karlsen $B$, Sæbø $\varnothing$. Analysis of mixed sequencing chromatograms and its application in direct 16S rRNA gene sequencing of polymicrobial samples. J Clin Microbiol. 2008:46:3766-71.

21. Haag H, Locher F, Nolte O. Molecular diagnosis of microbial aetiologies using SepsiTestTM in the daily routine of a diagnostic laboratory. Diagn Microbiol Infect Dis. Elsevier Inc.; 2013 [cited 2014 Mar 5];76:413-8. Available from: http://www.ncbi.nlm.nih.gov/pubmed/23747029.

22. Leitner E, Kessler HH, Spindelboeck W, Hoenigl M, Putz-Bankuti C, Stadlbauer-Köllner $\mathrm{V}$, et al. Comparison of two molecular assays with conventional blood culture for diagnosis of sepsis. J Microbiol Methods. Elsevier B.V.; 2013 [cited 2014 Apr 29];92:253-5. Available from: http://www. ncbi.nlm.nih.gov/pubmed/23266578

23. Burmølle M, Thomsen TR, Fazli M, Dige I, Christensen L, Homøe P, et al. Biofilms in chronic infections - a matter of opportunity - monospecies biofilms in multispecies infections. FEMS Immunol Med Microbiol. 2010 [cited 2014 Aug 25];59:324-36. Available from: http://www.ncbi.nlm.nih.gov/ pubmed/20602635.

24. SJ MC, Howlin R, Granger JF, Manring MM, Calhoun JH, Shirtliff M, et al. Biofilms in periprosthetic orthopedic infections. Future Microbiol. 2014;9: 987-1007. Available from: http://www.pubmedcentral.nih.gov/articlerender. fcgi?artid $=4407677 \&$ tool=pmcentrez\&rendertype=abstract

25. Bjarnsholt T, Alhede M, Alhede M, Eickhardt-Sørensen SR, Moser C, Kühl M, et al. The in vivo biofilm. Trends Microbiol. 2013 [cited 2014 Aug 12];21:466-74. Available from: http://www.ncbi.nlm.nih.gov/pubmed/23827084.

26. Hoffmann C, Leis A, Niederweis M, Plitzko JM, Engelhardt H. Disclosure of the mycobacterial outer membrane: cryo-electron tomography and vitreous sections reveal the lipid bilayer structure. Proc Natl Acad Sci U S A. 2008; 105:3963-7. Available from: http://www.ncbi.n/m.nih.gov/pubmed/18316738

27. Vandeventer PE, Weigel KM, Salazar J, Erwin B, Irvine B, Doebler R, et al. Mechanical disruption of lysis-resistant bacterial cells by use of a miniature, low-power, disposable device. J Clin Microbiol. 2011;49:2533-9.

\section{Submit your next manuscript to BioMed Central} and we will help you at every step:

- We accept pre-submission inquiries

- Our selector tool helps you to find the most relevant journal

- We provide round the clock customer support

- Convenient online submission

- Thorough peer review

- Inclusion in PubMed and all major indexing services

- Maximum visibility for your research

Submit your manuscript at www biomedcentral.com/submit
C BioMed Central 